\title{
SENIOR ON THE TOURISM MARKET
}

\author{
MONIKA ŚPIEWAK-SZYJKA
}

West Pomeranian University of Technology in Szczecin, POLAND

e-mail: monika.spiewak-szyjka@zut.edu.pl

RECEIVED
ACCEPTED
JEL
CLASSIFICATION

KEYWORDS

ABSTRACT
5 June 2017

12 November 2017

Q10, I 10, J 11

senior, tourist activity, tourist services

Positive influence of tourism activity on health and well-being of elderly people is undeniable, but tourism offer aimed at specific needs and abilities of this market section is relatively limited, although seniors constitute a growing and - as a result - more and more important group of customers with buying potential. Polish seniors, unlike their Western counterparts indicate a low level of tourism consumption.

The main reason for this situation is both a limited buying potential of Polish seniors, and the system of values in which tourism and other active ways of spending free time are relatively low in the rank.

The purpose of the review paper is to present the main aspects pointing at the need to treat seniors as important buyers of tourist and recreational services.

\section{Introduction}

Demographic changes are already triggering off many implications in different spheres of life and they are affecting the model of production, consumption, the structure of budget expenses, the job market, the system of insurance and social security benefits, investments, savings, social relations, family relations and people's lifestyle. Unfortunately, in the majority of analyses and commentaries dealing with this phenomena, the negative aspects of ageing and the related costs are mainly stressed.

The number of tourist farms which direct their offer at the seniors is increasing. They offer special diets, local amenities, facilities and special attractions that add variety to their leisure. Polish seniors follow their German neighbours' example and try to spend their retirement time visiting unknown regions. Oftener and oftener they decide on relaxation in the country thanks to which they gain peace and quiet. 
Taking into consideration the spending potential of seniors and the leisure at their disposal, one should state that the growing number of the elderly can be an enormous source of a boom in the economy of the widely understood farm tourism. The tourist offer, which is attractive and tailored to the senior consumer's possibilities and needs, serves for maintaining their intellectual and physical fitness, which translates into benefits for the whole society as well as for the whole economy.

\section{Literature review}

The precise defining of the term 'senior' is not an easy task. The term itself originates from the Latin language and means 'older' (from 'senex' - 'old'). While establishing the border between a grown up man and an older man, one may be guided by economic aspects (finishing work and going into retirement), cultural aspects (customs and traditions), social aspects (becoming a grandfather or grandmother), health aspects (deteriorating health and the loss of fitness).

In literature, it is a widely accepted fact that seniors are people who are 60 years old and over. This market requires a different treatment since seniors have their specific needs and expectations, their system of values and their own way of behaviour on the market. Besides, it is not a homogenous group; one can single out many diverse segments that may require quite a different marketing approach in terms of the difference in age which results in belonging to a given generation, a different course of the process of ageing, a diverse health condition, a different phase of the cycle of life, a financial and family situation, a different level of education and last but not least, the whole life style up to date (Śniadek, 2007).

In accordance with the definition passed by the First World Assembly on the Ageing of UN Societies in 1982, an older or elderly person (or an alternatively used term 'senior') is a person who is over 60 years old.

In Anglosaxon literature the old age is divided into three phases:

- the young old-people from between 60 and 65 to 74 years of age,

- the old old-people between 75 and 84 years of age,

- the oldest old-people who are 85 years old and over.

The young old are the people who are still fit both psychologically and physically. The people ranked within the old category are people who require assistance in doing some everyday activities. The oldest old need constant assistance in carrying out most of activities and people within this category are potential customers of institutionalized forms of assistance. In view of the fact that in Poland the average lifespan is shorter than that in West-European countries and a health condition of the old is worse, the age when a person requires a care assistant or assistance offered by specialized institutions is assumed to be between 75 and 80 years of age.

Simone de Beauvoir did not perceive the old age as one period and singled out two stages of the last phase of life assuming, as one of the criteria, the functional age, regarding the psycho-psychical capabilities of an old person:

- during the first stage the old are functionally independent but economically dependent (so called the third age),

- during the second stage the old are both functionally and economically dependent (so called the fourth age) (Report of the Institute of Labor and Social Affairs, 2012). 


\section{Method}

The analyses used the official data from the Main Statistical Office, the Ministry of Family, Labor and Social Policy and a questionnaire survey of 57 respondents aged from 20 to 65 years.

\section{Results}

The survey has revealed that the majority of those surveyed think that a senior is a person who is over 67 years old. Slightly less, $30 \%$ of respondents think that a senior is a person who is over 70 years old. $28 \%$ of those suyrveyed think that a senior is a person who is over 60 years old and barely $9 \%$ of survey participants think that a senior is a person who is over 50 years old.

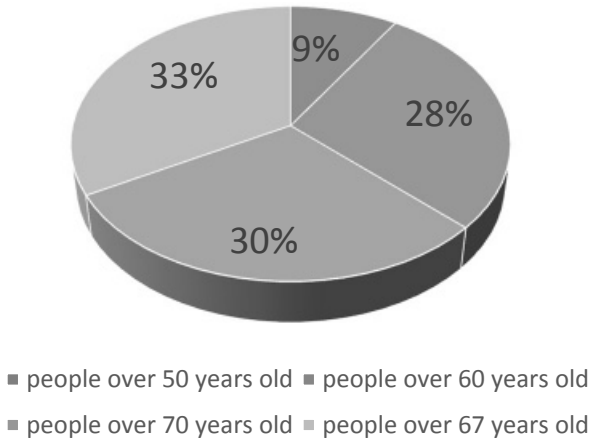

Figure 1. Respondents' opinion on the subject of the term "senior"

Source: Drawn up by the author on the basis of the surveyed data.

The process of ageing is a universal one. It accompanies the development of the world population albeit with some shifts in time. The dynamics of this process is very high, even higher than it used to be earlier in the old countries of the European Continent. The process of ageing was brought to attention as a result of the decrease both in birth rate and in death rate, which leads to the lengthening of the average lifespan. The world enters the third phase of demographic transition in which only the number of the old population grows.

Progressive socio-economical changes, the fasterand faster progress in technology and information-technology, the increase in the standard of living and the development of medicine and its achievements alongside contribute to the lengthening of the average human lifespan. The consequence of all the above mentioned is a faster growth of the number of people of the advanced age than the growth of newly born babies. Demographic problems are the main challenges that nowadays most European countries face.

According to projections for the population of Poland for the years 2014-2050, made by the Main Statistical Office, the population of Poland will be systematically decreasing until it reaches 36.5 million in the year 2035 and nearly 34 million in the year 2050.

That means that the population will be smaller by $11.8 \%$ in comparison to the year 2014 (that is by 4.5 million people) by the end of the estimated period. A negative birth rate will hold till the end of the range of the projections. 
It is predicted that the number of births will be systematically decreasing untill it reaches in the year 2050 a number almost $30 \%$ lower than it was at the beginning of the forecast. During the discussed period the average lifespan will be still lengthening - men will live to be 82.1 years old whereas women will live to be 87.5 years old on average and moreover the difference between men lifespan and women lifespan will decrease in a substantial manner, which means a lower men excessive mortality rate (Report of the Ministry of Family, Labor and Social Policy, 2016).

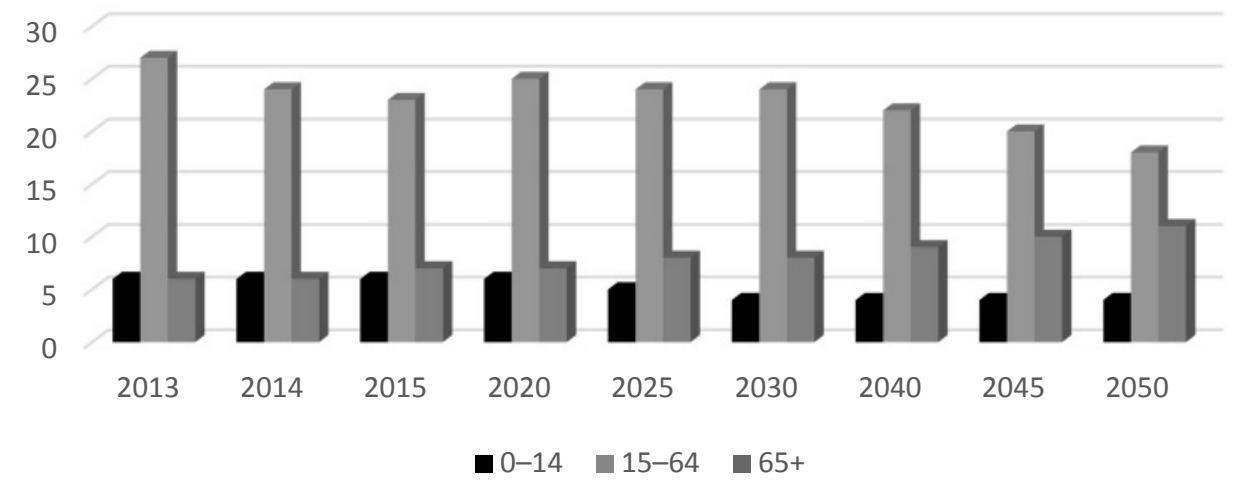

Figure 2. Forecast Polish population divided into biological age groups (in millions)

Source: drawn up by the author on the basis of the Main Statistical Office data.

The above data shows that the relationship between the number of births and the number of people at the age of $65+$ will start to decrease from the year 2020 onwards.

The primary causes of demographic ageing of societies are as follows:

- the decrease in birthrate,

- the decrease in mortality rate (especially in younger age groups),

- the lengthening of human lifespan, which results in the increase in the absolute number of the older population,

- migration processes leading, in some areas, to a considerable decrease in the percentage of young people in the community inhabiting those areas.

The analysis of the demographical situation shows that the process of ageing is progressing year by year. In addition to the previously mentioned causes, one may also add the emigration of younger years of people in search of work, a big social and spatial diversification and a deterioration in a living standard of many families. All those phenomena threaten a demographic development, which calls for a reaction from subjects responsible for politics. However, one must observe that a pro-family policy actually does not exist in Poland. A whole and strategic plan for pro-life activities is lacking. Solutions put forward by successive governments, among other things a baby birth benefit, a tax relief for children, one-year maternity leave and currently introduced the $500+$ programme all seem to be temporary activities and do not improve the whole situation in a meaningful and noticeable manner.

Polish seniors constitute a group which is often mariginalised in the light of the question of tourism issues. On one hand, one should not wonder at such a practice since in Poland the old and the elderly do not belong to a group 
which is the least active from a tourist's point of view. On the other hand, this tendency seems to be slowly changing. More and more seniors decide on some form or other of tourist activity. Admittedly, their number is still lower than that of seniors from western Europe, but it is not that low in comparison with other EU countries.

Emotional regulation considerably affects people's lifestyle and their coduct in the late adult age. The elderly suffer losses in many aspects:

- the loss of health, physical condition and physical attractiveness,

- the loss of loved ones,

- the loss of social and economical status,

- the loss of belongingness and prestige,

- the looming prospect of death.

All these situations may be a source of stress. Emotions of sadness and anxiety felt subjectively are much stronger at the old age than at the young age since they concern present experiences. The reaction of the autonomic nervous system is stronger as well. However, there are elderly people who, being conscious of a short life ahead of them, can focus on experiences which are emotionally positive. They often have an ability to fend off bad thoughts or not to think of uneasy situations which they cannot alter anyway. Physical fitness, a career success, friendship relations and friendly relations may be a source of positive emotions and give a sense of well-being (Dudek, Krukowski. Panas, 2014).

The Dutch are the society where people at the age of 65 and older are the most active in terms of long-term domestic trips as well as long-term trips abroad; over $61 \%$ of this population decide on such trips outdistancing German seniors (nearly $41 \%$ ) in this respect. However, German seniors are the most active in Europe in terms of trips abroad. People over 65 years of age in Germany make up about $15 \%$ of all people travelling abroad on holiday whereas in Belgium, France and GreatBritain the number amounts to a little less than $10 \%$. Such a big share of WestEuropean seniors in holiday trips is due to a high standard of living on retirement; especially the German pension system is generally regarded as one of the best worldwide (Śniadek, 2007).
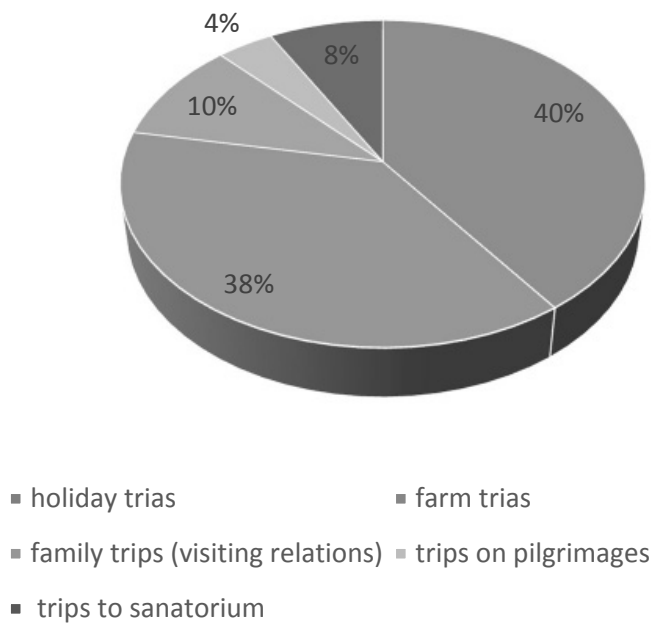

Figure 3. The elderly's preferences for tourist trias

Source: drawn up by the author based on a survey data. 
In Poland, the straight majority of the elderly go on domestic trips. It is understandable mainly for financial reasons but also for health reasons and for their outlook on life. A very small minority of travelling seniors use the services offered by travel agents, which is also quite understandable in view of a poor offer aimed specially at the elderly. In other EU countries, especially the rich ones, there are offers directed specially towards the elderly, which work both ways. On one hand, it is tour agents' answer to the elderly's interest, who have a sufficient capital and on the other hand, this kind of offers encourages elderly people to decide on package holiday. According to the surveyed, the minority of seniors decide on pilgrimages and family trips. More and more tourist farms aim their offer at seniors. They offer special diets, local amenities and facilities as well as special attractions which add variety to seniors' leisure. All this is supposed to encourage the elderly to rest and relax just at the tourist farms and nowhere else. Apart from that, a lot of groups go to sanatoriums or visit health-resorts located in different regions of the country. During their trips seniors prefer a peaceful rest filled up with short walks. Because of this, places visited by them are not usually popular among other tourists. Very often the elderly decide on a holiday trip or a health trip off-season due to lower prices and a smaller number of other tourists in holiday-resorts.

In the past, holidays for pensioners and seniors (the elderly) were not as common as they are today. Polish seniors used to travel very seldom and rather unwillingly. It is difficult to state unequivocally whether the situation was due to their slightly different mentality or to their lower wealth status. Nowadays, however, summer holiday trips (although not only summer trips as Polish seniors travel and rest outside home in all the seasons) are more and more popular among Polish seniors. It is a positive tendency because man should enjoy life at all ages.

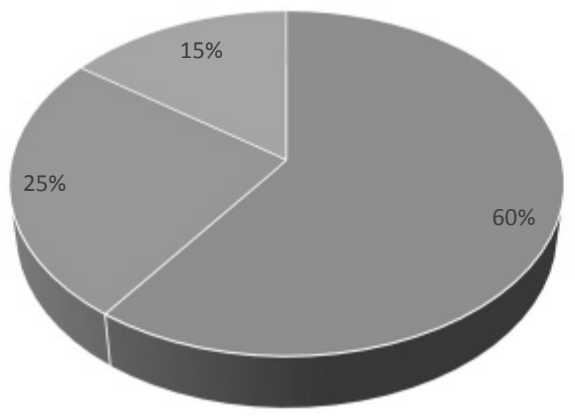

- trips to the Polish seaside - trips to the Polish mountains = trips abroad

Figure 4. The senior's preferences for tourist trips

Source: Drawn up by the author on the basis of a survey data.

The main destinations among Polish seniors are spots and places with a high level of tourist popularity, in which case the senior's preferences do not diverge much from those of the general public. The most popular destinations are trips to the Baltic sea and to the south of Poland. Fewer seniors go on holiday abroad. One may assume that it is conditioned by their financial situation, the state of their health and by security reasons as well. 


\section{Conclusions}

To sum up, one can find that apart from the actions and ecouragement aimed directly at the elderly there also appears a need for a universal social campaign for the restoration of the senior's positive image which was lost, to a high degree, due to the wrong pension policy and to the really huge budget charge with the costs of pensions.

Therefore, there arises a need for developing (building and modernizing) the tourist and recreational infrustructure adjusted to the elderly's needs. That is why, the country's institutions and organisations responsible for the elderly's issues as well as $r$ the social and economic policy ought to take advantage of the looming 'demographical crises' as an opportunity for rebuilding the society and the economy in which both present and future senior consumers will find their important place as they constitute a long-term segment of the tourist and recreational market.

\section{References}

Dudek, M., Krukowski, J., Panas, K. (2014). Rzeczywistość seniora. Warszawa: Wyższa Szkoła Menedżerska w Warszawie.

Golinowska, S. (2010). System zabezpieczenia społecznego w Polsce wobec uwarunkowań przyszłości. Warszawa: Narodowa Rada Rozwoju.

Szatur-Jaworska, B. (2006). Podstawy gerontologii społecznej. Warszawa: Oficyna Wydawnicza ASPRA-JR.

Schimanek, T. (2010). Społeczne uwarunkowania i konsekwencje niskiej aktywności zawodowej osób 50+ oraz rozwiązania służące jej zwiększeniu. In: Aktywizacja zawodowa osób 50+ i zarządzanie wiekiem. Informacje użyteczne dla instytucji rynku pracy. Warszawa: Akademia Rozwoju Filantropii w Polsce.

Śniadek, J. (2007). Konsumpcja turystyczna seniorów. Gerontologia Polska, 1-2 (15).

Raport Ministerstwa Rodziny, Pracy i Polityki Społecznej 2016, Osoby powyżej 50. roku życia na rynku pracy w 2015 r. Warszawa.

Raport na temat sytuacji osób starszych w Polsce 2012. Warszawa: Instytut Pracy i Spraw Socjalnych.

Kobiety i Mężczyźni na rynku pracy (2016). Warszawa: Główny Urząd Statystyczny.

Założenia Długofalowej Polityki Senioralnej w Polsce na lata 2014-2020, zał. do uchwały nr 238 Rady Ministrów z dnia 24 grudnia 2013 r. (poz. 118).

Cite this article aS: Śpiewak-Szyjka, M. (2017). Senior on the tourism market. European Journal of Service Management, 4 (24), 59-65. DOI: 1.18276/ejsm.2017.24-09. 
